\title{
Erratum to: Process capability index for AC transformer under electrical harmonics
}

Luis Carlos Méndez-González ${ }^{1}$ • Luis Alberto Rodríguez-Picón ${ }^{1}$. Abel Eduardo Quezada-Carreón ${ }^{2}$ - Roberto Romero-López ${ }^{1}$ • Vicente Garcia ${ }^{2}$

Published online: 7 March 2017

(C) Springer-Verlag Berlin Heidelberg 2017

\section{Erratum to: Electr Eng}

DOI 10.1007/s00202-017-0509-3

In the original publication of the article, the name of the second author was published incorrectly as "Luis Alberto Rodrígez-Picón". The correct name should be "Luis Alberto Rodríguez-Picón". The original article has been updated accordingly.

The online version of the original article can be found under doi:10.1007/s00202-017-0509-3.

Luis Carlos Méndez-González

luis.mendez@uacj.mx

1 Department of Industrial Engineering and Manufacturing, Institute of Engineering and Technology, Universidad Autónoma de Ciudad Juárez, Ciudad Juárez, Chihuahua, Mexico

2 Department of Electrical and Computer Engineering, Institute of Engineering and Technology, Universidad Autónoma de Ciudad Juárez, Ciudad Juárez, Chihuahua, Mexico 